http://kitaibelia.unideb.hu/
ISSN 2064-4507 (Online) • ISSN 1219-9672 (Print)
(C) 2015, Department of Botany, University of Debrecen, Hungary
20 (2): 254-258.; 2015
DOI: 10.17542/kit.20.254

\title{
A Viola collina Besser előfordulása a Bükkben és az Upponyi-hegységben
}

\author{
SUlYOK József ${ }^{1}$, VojTKó András ${ }^{2} \&$ SoMLYAY Lajos ${ }^{3}$ \\ (1) Bükki Nemzeti Park Igazgatóság, H-3300 Eger, Sánc út. 6.; sulyokj70@gmail.com \\ (2) Eszterházy Károly Főiskola, Növénytani és Ökológiai Tanszék, H-3300 Eger, Pf. 43. \\ (3) Magyar Természettudományi Múzeum, Növénytár, H-1476 Budapest, Pf. 222.
}

\section{The occurrence of Viola collina Besser in the Bükk and Uppony Mts. (N Hungary)}

\begin{abstract}
Herbarium revisions and recent field observations revealed the occurrence of Viola collina Besser in the Bükk and Uppony Mts. (northern Hungary). This species has not been reported from the North Hungarian Mountains thus far. Altogether 94 localities of $V$. collina have been recorded in that region between 2007 and 2014. A map of the species' local distribution is provided. Local habitat preferences of $V$. collina are briefly discussed.
\end{abstract}

Keywords: distribution, flora, habitat preference, Hungary, North Hungarian Mountain Range, Violaceae

Összefoglalás - Herbáriumi revízió és terepi megfigyelések alapján a Viola collina Besser új bükki és upponyi-hegységi előfordulásairól adunk hírt, amelyek egyúttal a faj első publikált adatai az Északiközéphegység területéről. A 94 előfordulási adatot 2007 és 2014 között gyűjtöttük. Mindezek alapján közöljük a faj regionális elterjedési térképét, valamint röviden jellemezzük a növény élőhelyi és társulástani preferenciáját.

Kulcsszavak: elterjedés, élőhely-preferencia, Északi-középhegység, flóra, Magyarország, Violaceae

\section{Bevezetés}

A dombi ibolya (Viola collina Besser) hazai elterjedésének feltárása egy újabb szakaszhoz érkezett. Az elmúlt évtizedekben a Dunántúli-középhegység területén végzett szisztematikus kutatások révén szépen kirajzolódott a faj regionális elterjedése, és jobban megismertük az ökológiai igényeit (MÉszÁros 1997, FARKAS 1999, BAUER \& MÉszÁros 2000, KovÁCS 2000, BARINA 2006, 2007, BAUER 2008, 2014, SOMLYAY 2009, 2011). A fajt az Északiközéphegységből eddig nem ismertük (vö. Soó 1968, 1980, FARKAS 1999, FARKAS 2009). Dolgozatunkban az utóbbi években ismertté vált itteni adatait mutatjuk be.

\section{Eredmények}

A Viola collina Besser az Északi-középhegységben hiányosan ismert faj, amelynek eddigi bükki „rejtőzködése” az alkalmas élőhelyeken talált egyedek $V$. hirta L.-ként történő téves azonosítására vezethető vissza. Első bükki bizonyító példánya (BP 481029) a felsőtárkányi Kecskor-hegyese és Balázs-hegy vonulatából származik, ahol a „vegetációtérképezők” (Jakucs Pál, Fekete Gábor, Baráth Zoltán) gyüjtötték V. hirta néven 1954. július 10-én („Viola hirta L. Bükk hgs. Felsôtárkány. Samassa. Balázs hegy-Kecskor."). A térképezők ezen a napon a 
Kecskor-hegyese nyugati kőtörmelékes oldalában lévő „igen érdekes Tilio-Fraxinetum-ba hajló Querceto-Lithospermetum, illetve Cotinetum társulásból" készítettek felvételeket, amelyben idős bükkök is előfordultak (BARÁTH et al. 1954). A növény eddigi bükki lelőhelyeinek ismeretében valószínűleg itt gyűjthették a példányt, amelyet Pavol Mered’a 2007-ben $V$. collina-ként revideált.

Hasonlóan téves határozás miatt sikkadt el Zólyomi Bálint jávor-hegyi adata is, amelyet cönológiai felvételezés közben $V$. hirta-ként jegyzett fel 1959. június 17-én (TöRöK \& ZóLYOMI 1998). A jól beazonosítható helyszínt 2012-ben bejártuk, és a hegy sziklagyepjében és sziklaerdeiben csak a V. collina egyedei kerültek elő nagy egyedszámban.

Az első élő növény bükki előkerülésére 2007. május 10-ig kellett várni: Vojtkó András az Ómassa fölötti Szuszogó sziklaerdejében szedte. Pifkó Dániel és Christian Bräuchler a Bélkőn végzett terepbejárás alkalmával gyüjtötték 2010. szeptember 4-én. Az újabb bizonyító példányok előkerülése Somlyay Lajos nevéhez füződik, aki 2011. április 24-én a felsőtárkányi Vár-hegyen és a noszvaji Bükkös-tetőn (Gallas-bükkös), majd 2011. május 7-én az egri Bikkbércen és a felsőtárkányi Csák-Pilis és Vár-hegy több pontján is gyűjtötte. Ezt követően, 2012ben kezdtük el a növény szisztematikus keresését, amelynek eredményeként eddig 96 lelőhelyen, több mint 4000 egyede került elő. A potenciális élőhelyek ellenőrzése még nem ért véget, így ez a szám korántsem tekinthető véglegesnek.

Előfordulásait 207 és $901 \mathrm{~m}$ tszf. közötti magasságban, számos növénytársulásban megtaláltuk. Elsősorban a montánabb, reliktumőrző élőhelyek növénye, de a hegység déli részein is előfordulnak jelentős egyedszámú állományai, főként dolomiton és eocén mészkövön. A $\quad V$. collina északi-középhegységi élőhely-preferenciáival kapcsolatban előzetesen megállapítható, hogy jellemzően sziklaerdókben [Seslerio hungaricae-Fagetum Zólyomi 1967, Epipactio atrorubentis-Fagetum Less 1998, Tilio-Sorbetum Zólyomi et Jakucs (1957) 1967, Tilio-Fraxinetum Zólyomi (1934) 1967, Seslerio hungaricae-Quercetum virgilanae Suba et al. 1982, Cirsio pannonici-Quercetum Less 1998] és sziklagyepekben [Seslerietum heuflerianae-hungaricae Zólyomi (1936) 1966, Calamagrostio variaeSeslerietum variae Vojtkó 1998, Inulo ensifoliae-Seslerietum hungaricae Vojtkó 1998, Campanulo divergentiformis-Festucetum pallentis Zólyomi 1966], ritkábban ezek zonális társulással érintkező kőtörmelékes átmeneti állományaiban (például Aconito-Fagetum Soó 1960) találja meg életfeltételeit. Rábukkantunk azonban másodlagos élőhelyen is, például a bánkúti sípálya (Felső-Borókás) degradált gyepjében, dolomiton. A részletes felvételezés és annak feldolgozása a jövő feladata.

A hazánkban dunántúli fajnak tartott $V$. collina-ról BAUER \& MÉszÁros (2000) azt feltételezik, hogy nálunk posztglaciális reliktum faj, amelyet a bükki előfordulások ökológiai viszonyai is megerősíteni látszanak.

\section{Enumeráció}

Adatközlők: PD \& CB - Pifkó Dániel és Christian Bräuchler, SL - Somlyay Lajos, SJ - Sulyok József, VA -Vojtkó András; a külön nem jelzettek Sulyok József adatai.

A felsorolásban használt dűlőnevek alapját az M 1:10.000-es méretarányú EOV vetületi rendszerű topográfiai térképek, a külterületi kataszteri térképek, a katonai felmérések térképei, turistatérképek, erdészeti térképek és a Heves megyei helységnévtár névanyaga képezi, kiegészítve saját helyi gyűjtésekkel.

Az enumerációban feltüntettük az érintett flóratérképezési negyed-kvadrátok azonosítóit is, KIRÁLY (2003) munkája alapján. 


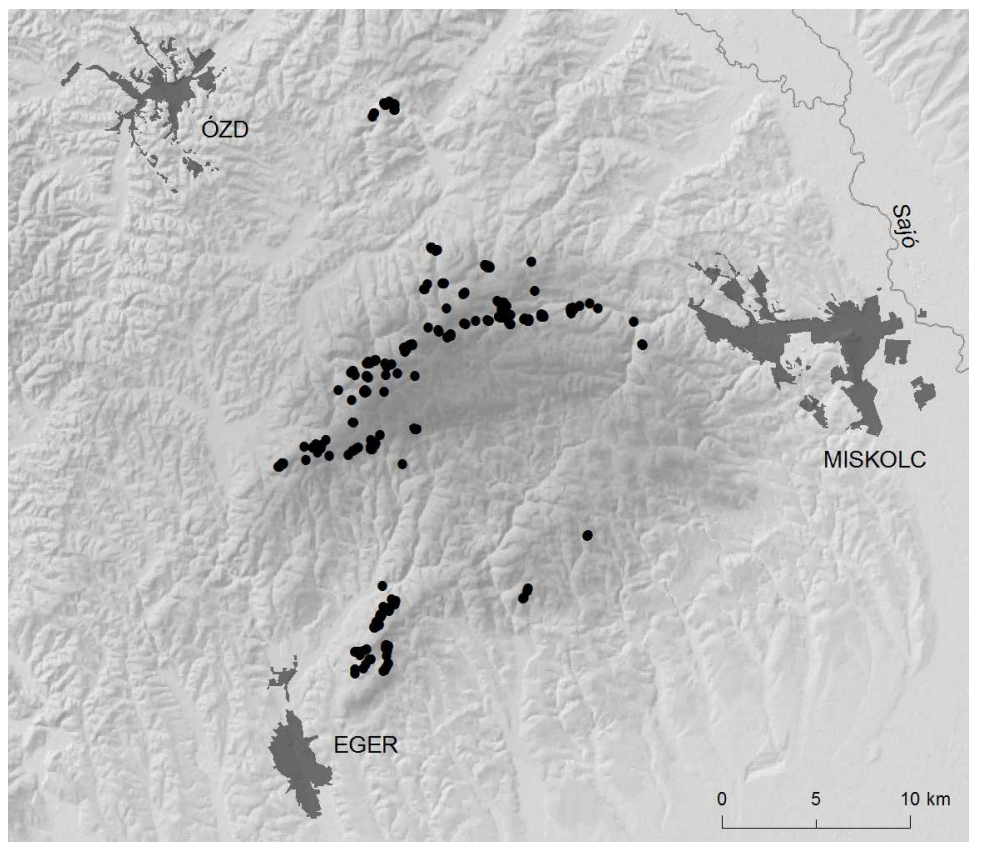

1. ábra. A Viola collina Besser eddig észlelt lelőhelyei a Bükkben és az Upponyi-hegységben.

Fig. 1. Known occurrences of Viola collina Besser in the Bükk and Uppony Mts.

\section{Bükk-fennsík}

Bélapátfalva: Hegyes-kő (SJ \& SL) [7988.4]; Felsőtárkány: Cserepes-kő (SJ \& SL) [7988.2], [7988.4], Hegyes-kő (SJ \& SL), Pes-kő (SJ \& SL) [7988.4], Tar-kő [7988.2]; Mályinka: Nyár-Újhegy, Ördög-oldal [7888.4]; Miskolc: Alabástrom-hegy, Alsó-Borovnyák, Alsó-Sebes - az Alsó-Sebes-víz völgytől keletre lévő hegy, Angyal-kő - a Száraz-völgy és Angyal-völgy torkolata fölött lévő dolomit kúp (SJ \& SL), Bem Apó-kő - a Nyár-Új-hegytől délre lévő hegy (SJ \& SL) [7889.3], Demény-hegy - a Kovács-kő DK-i gerince [7889.4], Felső-Borókás [7888.4], Hetemér, Heteméri-sziklák (SJ \& SL), Jávor-hegy, Látó-kő (SJ \& SL), Massai-tető Ómassától északra lévő hegy (SJ \& SL) [7889.3], Nyavalyási dolomit bánya környezete [7889.3], [7889.4], Nyavalyás-bérc - Miskolc-Garadnától délre lévő hegy (SJ \& SL), Ómassai Vörös-kő (SJ \& SL), Sólyom-kő (SJ \& SL), Szentlélek, Szuszogó (VA); Vörös-kő-tető - az ómassai Vörös-kő fölötti gerinc (SJ \& SL) [7889.3]; Nagyvisnyó: Huta-rét, Leány-hegy, Ölyves-völgy-fő; Szilvásvárad: Cserepes-kő (SJ \& SL), Ispán-hegy, Istállós-kő, Kis-Vörös-kőbérc - a Vörös-kő-bérc déli gerince (SJ \& SL), Küllő-hegy [7988.2], Pes-kő (SJ \& SL) [7988.4], Tar-kő [7988.2], Vörös-sár-hegy [7988.2]; Varbó: Gyurkó-tető - a Sövény-kúttól északra lévő gerinc (SJ \& SL) [7889.3].

\section{Északi-Bükk}

Bélapátfalva: Bél-kő (PD \& CB), Bél-kő-nyak, Felső-erdő [7988.3], Ivánka (SJ \& SL) [7988.1], Jegető - a Messzelátó északi gerincének sziklája, Messzelátó (SJ \& SL), Ördög-hegy (SJ \& SL), Szamár-kő [7988.3]; Dédestapolcsány: Baróc-völgy [7888.4]; Felsôtárkány: Sándor-hegy (SJ \& SL) [7988.3]; Mályinka: Bartos-kő - a Csondró-völgy-Kemesnye-völgy torkolatától DK-re lévő szikla (Odvas-kő) [7889.3], Csattató-kő [7888.4], Kapu-bérc (SJ \& SL) [7889.3], Mártuskő, Szőlő-köve-bérc - a Csattató-kőtől ÉNy-ra lévő gerinc [7888.4]; Nagyvisnyó: Ablakos-kő, Ablakos-kő-völgy, Gerenna-vár (SJ \& SL), Király-szikla [7988.2], Közép-orom, Ördög-oldal, 
Pados [7888.4], Párna-hegy, Tamás-kő [7988.2], Vásárhely-kő [7888.4]; Szilvásvárad: Éleskő-vár, Gerenna-vár (SJ \& SL), Holló-kő (SJ \& SL), Kukucsó-völgy [7988.2], Nagy-verő (SJ \& SL) [7988.1], Róna-bükk (SJ \& SL) [7988.2].

\section{Déli-Bükk}

Cserépfalu: Kerékkötő - a Miklós-Luga és a Kerékkötő-hegy közötti hegy (SJ \& SL), Kerékkötő-hegy (SJ \& SL) [7989.4], Kis-galya (SJ \& SL), Kis-Piliske (SJ \& SL) [8089.1]; Eger: Bikk-bérc (SL) [8088.4]; Felsótárkány: Balázs-kő („vegetációtérképezők”) [7988.4], Bikkbérc [8088.4], Bükkös-tető [8088.2], [8088.4], Csák-Pilis (SL), Csák-Pilis-tető - Vár-hegy vonulat legészakibb kúpja, Dolomitbánya (SL) - tömeges, Felső-Kuklya [8088.2], Fenék-oldal - a Miklós-völgy ÉK-i oldalának kis dolomit kúpja [8088.2], [8088.4], Kis-Tiba-hegy [8088.4], Kőköz [8088.2], Miklós-völgy [8088.4], Nagy-Oltár - A Vár-hegy Miklós-völgyre néző Ny-i nyúlványa (SL) - tömeges [8088.2], [8088.4], Nagy-Tiba-hegy [8088.4], Sasdúlő-nyak [8088.2], Szénégető-lápa [8088.4], Vasbánya-hegy [8088.2]; Miskolc: Dolka-hegy - a Hámoritó gátjától északra lévő hegy (SJ \& SL) [7889.4], Fehér-kő, Fehér-kő-lápa-tető (SJ \& SL) [7989.2]; Noszvaj: Bükkös-tető (Gallas-bükkös) (SL) [8088.2].

\section{Upponyi-hegység}

Uppony: Dedevár, Upponyi-szoros (SJ \& SL), Vízköz (SJ \& SL), Vízköz-szoros - a Csernelypatak völgyének részben egykor bányászott szúkülete, a településtől délre (SJ \& SL) [7788.4].

\section{Köszönetnyilvánítás}

Köszönjük Pifkó Dánielnek és Christian Bräuchlernek publikálatlan adatuk rendelkezésünkre bocsátását. A harmadik szerző munkáját a K 108992 számú, „Magyarország veszélyeztetett hajtásos növényeinek ritkasága, életmenet-jellemzői és klímaválasza" címü OTKA pályázat támogatta.

\section{Irodalom}

Baráth Z., Horánszky A., Jakucs P., Pócs T. \& Zólyomi B. (1954): A Bükk-hegységi vegetációtérképezési munka 1954. évi jegyzókönyve. - Kézirat, Eger, pp. 6-7.

BARINA Z. (2006): A Gerecse hegység flórája. - Rosalia 1, Magyar Természettudományi Múzeum - DunaIpoly Nemzeti Park Igazgatóság, Budapest, 336 pp.

BARINA Z. (2007): A Vértes és környéke florisztikai kutatásának eredményei I. - Kitaibelia 12: 30-40.

BAUER N. (2008): Viola collina Bess. a Pilis hegységben. - Flora Pannonica 6: 128.

BAUER N. (2014) A Bakony-vidék szárazgyepjei - Sztyeprétek és sziklagyepek osztályozása és növényföldrajzi karaktere (Dry grasslands of the Bakony Region - Classification and phytogeographical character of dry and rocky grasslands). - MTM, Budapest, A Bakony természettudományi kutatásának eredményei 33: 336 pp.

BAuer N. \& MÉszáros A. (2000): A Viola collina BESs. új előfordulásai és cönológiai viszonyai a Bakonyban. - Folia Mus. Hist.-Nat. Bakonyiensis 16: 75-92.

FARKAS S. (1999): Viola collina Bess. Dombi ibolya. - In: FARKAS S. (szerk.), Magyarország védett növényei. Mezőgazda Kiadó, Budapest, p. 221.

FARKAS S. (2009): Violaceae - Ibolyafélék családja - In: KiRÁly G. (szerk.), Új Magyar füvészkönyv. Magyarország hajtásos növényei. Határozókulcsok. Aggteleki Nemzeti Park Igazgatóság, Jósvafö, p. 289.

KIRÁLY G. (2003): A magyarországi flóratérképezés módszertani alapjai. Útmutató és magyarázat hálótérképezési adatlapok használatához. - Flora Pannonica 1: 3-20.

KovÁcs J. A. (2000): Dolomit-mészkő sziklagyepek és lejtősztyepek helyzetéről a Déli-Bakonyban. Kanitzia 8: 39-50. 
MÉSZÁRos A. (1997): Adatok Várpalota környékének flórájához. - Kitaibelia 2: 51-55.

SomLYAY L. (2009): A Budai-hegység florisztikai növényföldrajzának fő vonásai. - Kitaibelia 14: 35-68.

Somlyay L. (2011): Adatok Budapest környéke flórájának ismeretéhez. - Kitaibelia 15 [2010]: 101-108.

Soó R. (1968): A magyar flóra és vegetáció rendszertani-növényföldrajzi kézikönyve 3. - Akadémiai Kiadó, Budapest, 506 pp.

Soó R. (1980): A magyar flóra és vegetáció rendszertani-növényföldrajzi kézikönyve 6. - Akadémiai Kiadó, Budapest, 557 pp.

TöRöK K. \& ZóLYOMI B. (1998): A Kárpát-medence öt sziklagyeptársulásának szüntaxonómiai revíziója. In: Csontos P. (szerk.), Sziklagyepek szünbotanikai kutatása. Scientia Kiadó, Budapest, pp. 109-132.

Beérkezett / received: 2015. 03. 16. • Elfogadva / accepted: 2015. 04. 15. 